\title{
EATING DISORDER AND DEPRESSION AMONG PUBLIC SERVANTS IN AKWA IBOM STATE, NIGERIA
}

\author{
Dr. (Mrs.) Janet S Petters ${ }^{1} \boldsymbol{U}$, Dr. (Mrs.) Umo Udeme Akaninyene $2 \mathbb{}$ (iD \\ ${ }^{1}$ Department of Guidance and Counselling, University of Calabar, Calabar, Nigeria \\ 2 Department of Educational Foundations, University of Calabar, Calabar, Nigeria
}

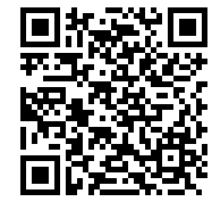

DOI: https://doi.org/10.29121/granthaalayah.v8.i9.2020.1319

Article Type: Research Article

Article Citation: Dr. (Mrs.) Janet S Petters, and Dr. (Mrs.) Umo, Udeme Akaninyene. (2020). EATING DISORDER AND DEPRESSION AMONG PUBLIC SERVANTS IN AKWA IBOM STATE, NIGERIA. International Journal of Research GRANTHAALAYAH, 8(9), 147-152. https://doi.org/10.29121/granthaa layah.v8.i9.2020.1319

Received Date: 25 August 2020

Accepted Date: 30 September 2020

Keywords:

Eating

Disorder

Depression

Public Servants

\section{ABSTRACT}

This study was carried out to establish the relationship between eating disorder and depression among public servants in Akwa Ibom State, Nigeria. The study adopted the expost facto design. The sample consisted of 1000 (533 males, 467 females) public servants who were randomly selected from state ministries, schools, boards and parastatals in the state. A Public Servant Opinion Questionnaire (PSOQ) constructed by the researcher was used for data collection. A null hypothesis was tested in the study using the Pearson Product Moment Correlation Coefficient. This paper also highlights some causes and mechanisms of eating disorder and depression, biological or genetic factors and addiction. The major findings indicated that eating disorder significantly led to some degree of depression, which is a mental illness. Based on this result, it was concluded that eating disorder was a significant factor in explaining the incidence of depression. The major recommendations are that depressed people should be referred to seek the services of social psychologists, psychotherapists, and clinical psychologists in psychiatric hospitals, and also that, government should help in providing good working conditions for her staff.

\section{INTRODUCTION}

Individuals at one time or the other have unique experiences that serve to influence their personal life and general well-being, one of such experience is the feeling of depression. Depression is a plunge (sudden change) in mood, so severe and prolonged that is possible to ultimately overwhelm the entire personality, rendering various lives functions to grant to a halt (Kegan, Havanen \& Segal, 1984).

Eating disorders are characterized with food and weight. This can be attributed to the fact that society is seen to put an emphasis on women to be thin, and men to be 'bulked up'. This can lead to pressure on women to be 'picture perfect'; and, eating disorders prevails as a result of stress of not being able to reach unattainable goals related to this 'picture perfect' ideal (Crandall, 1995 and Umo, 2009).

Appearance is a major concern for most public servants, especially women. One possibility is that, from infancy on, people place more emphasis on the appearance of females than of males. This can be a potential contributor to depression, as a mental illness (Baron \& Bryne, 2002).

An eating disorder is a complex compulsion to eat, or not eat, in a way which disturbs the physical and mental health of an individual. The eating may be excessive (compulsive overeating); too limited (restricting); may include

(C) 2020 The Author(s). This is an open access article distributed under the terms of the Creative Commons Attribution License, which permits unrestricted use, distribution, and reproduction in any medium, provided the original author and source are credited. 
cycles of bringing and purging; or may encompass the ingesting on non-foods. The most heard about eating disorders are Anorexia nervosa and Bulimia nervosa, but, the most widely and rapidly spread eating disorder is compulsive overheating or binge eating disorder. All these have severe consequences to a persons' immediate and long-term mental health and can cause death. (Baron \& Bryne, 2002; Yager \& Anderson, 2005)

Public servants appear to be working under unfavourable and degrading conditions, where salaries are irregularly paid, with social and psychological consequences especially on those with dependants. It is obviously noticed that some public servants do leave their places of work before closing time to be seen in "goat meat pepper soup" joints, restaurants, fast food shops, eating in-between meals to the detriment of their jobs, self-image and interpersonal relationships. Some binge eaters, as a result of frustration both at home and office, eat to fill emotional void of spiritual emptiness they feel, in a desperate effort to be satisfied. This is called, emotional eating, which deals with coping mechanism for anxiety, anger, stress, depression and many other negative emotions (Long, 1993; Umo, 2009).

Public servants with eating disorders experiences como-bid diagnosis of mood disorder, severe mental depression, obsessive compulsive disorder, body-dimorphic disorder, self-harm personality disorder, substance abuse disorder and sexual abuse is also frequently reported among those with eating disorders (Kriz, 2002). Women with eating disorders show poorer eating self-efficacy, psychological distress, disinhibition, less helpful coping strategies, more frequent sensations of hunger, and less cognitive restraint, compare to control groups (Uher \& Treasure, 2005; Umo, 2017).

This paper focuses on eating disorder and depression. The aim is to examine from theoretical and practical perspectives how eating disorders and depression could be minimized, while maximizing productivity among public servants in Akwa Ibom State, and generally in Nigeria. How do public servants be integrated into a work environment that meets their satisfaction? In what ways can the government or individuals help reduce home and work related depression? To what extent can this study draw the attention of both the public servants and the government, to the enormous harm caused by eating disorder and depression? How can government address this undeniable existing problem, which they seem not to notice, even when they are calling for high productivity?

\section{CAUSES AND MECHANISMS OF EATING DISORDERS: ENVIRONMENTAL FACTORS}

The media may be a significant influence on eating disorders through its impact on values, norms and image standards accepted by modem society. Both societies' exposure to media and eating disorders has grown immensely and clinicians are finding ways to reduce the negative influence of thin-ideal media has on women's body perception and susceptibility to eating disorders. The dieting industry makes a lot of money each year by consumers continually buying products in an effort to strive for an unattainable appearance. It takes enormous toll on one's selfesteem, as it can lead to dieting behaviours, body shame and eating disorder (Harrison \& Cantor, 1997).

\subsection{FAMILY RELATIONSHIPS}

In conditions of criticism and coercive parental control during childhood, women create rules for themselves, through using food refusal to gain autonomy and control over their environment (Hawarth-Hoeppner, 2000). Hoeppner opined that, women who experienced physical or sexual abuse as a child end up with eating disorders, as a method of punishing oneself, due to the feeling of low self-esteem and worthlessness, so they can finally receive love and acceptance they lacked during childhood. They equally abide by food rules (Howorth-Hoeppner, 2000; Cvetkovich, 2012).

\subsection{BIOLOGICAL/ GENETIC FACTORS}

Uher and Treasure (2005) opined that, people suffering from eating disorder are highly correlated with having depression and obsessive compulsive disorder. Bulimic patients were found to have lower normal neurotransmitter levels such as serotonin, cholecystokinin dopamine and norepinephrine (hormones), which are released as one eat. People, who are lacking these hormones, are more likely to lack feeling of satisfaction while eating, which can lead to binge eating. 
Dr. (Mrs.) Janet S Petters, and Dr. (Mrs.) Umo, Udeme Akaninyene

Kalat (2004) also explained that, over eating is associated with abnormalities in neuromodulator peptides, leptin and cortisol which are hormonal imbalance caused by a problem in or around the hypothalamus in the brain. Damage to the hypothalamus can result in abnormalities in temperature regulation, eating, drinking, sexual behaviour, fighting, self-induced vomiting, over concerned with becoming fat, cheating with eating, frequent sleepiness, diabetes insipidus and depression (Kalat, 2004; Davey et al., 2008).

\subsection{ADDICTION}

Personality factors place individuals at risk for substance abuse. With addiction and eating disorders, individuals discharge affective experience through action, rather than feeling, or being able to talk about them, inability to regulate tension, need for immediate gratification, poor impulsive control, as a fragile sense of self In those with eating disorders, substance abuse, drugs or alcohol is used in attempts to avoid binge eating; which they deny or attempt to keep it secret, trying to conceal their usage (Werner, 1998, Cash, 1995, Crandall, 1995, Lavine, Sweeney \& Wagner, 1999, Numbers, 1999, Catterin, Thompson, Thomas \& Williams, 2000, Wiederman, 2000, Strong, Williamson, Netemeyer \& Geer, 2000, Vincent \& McCabe, 2000; Rashid \& Heider, 2008).

\section{METHODOLOGY}

To establish the relationship between eating disorders and depression, the sample was selected through the stratified random sampling method, which comprised of 1000 (533 males, 467 females) public servants on grade level 05 and above. Also, male and female staffs (gender) were considered, as well as their age. In using stratification, the likely error in sampling was reduced and this increased the probability of making valid generalization. (See table 1)

Table 1: Distribution of subjects in the main study by location, age and gender

\begin{tabular}{|c|c|c|c|c|c|c|c|c|c|c|c|c|c|c|c|c|c|c|c|c|c|c|c|c|}
\hline Age & \multicolumn{2}{|c|}{$\begin{array}{l}21- \\
25\end{array}$} & & \multicolumn{2}{|c|}{$\begin{array}{l}26- \\
30\end{array}$} & & \multicolumn{2}{|c|}{$\begin{array}{c}31- \\
35\end{array}$} & & \multicolumn{2}{|c|}{$\begin{array}{c}36- \\
40\end{array}$} & & \multicolumn{2}{|c|}{$\begin{array}{l}41- \\
45\end{array}$} & & \multicolumn{2}{|c|}{$\begin{array}{l}46- \\
50\end{array}$} & \multicolumn{3}{|c|}{$50+$} & & \multicolumn{3}{|c|}{ TOTAL } \\
\hline Gender & $\mathrm{M}$ & $\mathrm{F}$ & $\mathrm{T}$ & $\mathrm{M}$ & $\mathrm{F}$ & $\mathrm{T}$ & $\mathrm{M}$ & $\mathrm{F}$ & $\mathrm{T}$ & $\mathrm{M}$ & $\mathrm{F}$ & $\mathrm{T}$ & $\mathrm{M}$ & $\mathrm{F}$ & $\mathrm{T}$ & $\mathrm{M}$ & $\mathrm{F}$ & $\mathrm{T}$ & $\mathrm{M}$ & $\mathrm{F}$ & $\mathrm{T}$ & $\mathrm{M}$ & $\mathrm{F}$ & $\mathrm{T}$ \\
\hline $\begin{array}{c}\text { Ministr } \\
\text { ies }\end{array}$ & $\begin{array}{l}2 \\
0\end{array}$ & $\begin{array}{l}2 \\
4\end{array}$ & 44 & $\begin{array}{l}3 \\
0\end{array}$ & $\begin{array}{l}2 \\
4\end{array}$ & 54 & $\begin{array}{l}2 \\
5\end{array}$ & $\begin{array}{l}2 \\
3\end{array}$ & $\begin{array}{l}4 \\
8\end{array}$ & $\begin{array}{l}2 \\
7\end{array}$ & $\begin{array}{l}1 \\
6\end{array}$ & 48 & $\begin{array}{l}1 \\
3\end{array}$ & $\begin{array}{l}1 \\
0\end{array}$ & 33 & $\begin{array}{l}1 \\
0\end{array}$ & 8 & $\begin{array}{l}1 \\
8\end{array}$ & $\begin{array}{l}1 \\
5\end{array}$ & 4 & $\begin{array}{l}1 \\
9\end{array}$ & $\begin{array}{c}14 \\
0\end{array}$ & $\begin{array}{c}10 \\
9\end{array}$ & $\begin{array}{c}24 \\
9\end{array}$ \\
\hline $\begin{array}{c}\text { School } \\
\text { S }\end{array}$ & $\begin{array}{l}2 \\
0\end{array}$ & $\begin{array}{l}2 \\
4\end{array}$ & 44 & $\begin{array}{l}2 \\
2\end{array}$ & $\begin{array}{l}2 \\
8\end{array}$ & 50 & $\begin{array}{l}2 \\
0\end{array}$ & $\begin{array}{l}2 \\
8\end{array}$ & $\begin{array}{l}4 \\
8\end{array}$ & $\begin{array}{l}2 \\
2\end{array}$ & $\begin{array}{l}3 \\
8\end{array}$ & 60 & $\begin{array}{l}1 \\
0\end{array}$ & $\begin{array}{l}2 \\
6\end{array}$ & 36 & $\begin{array}{l}1 \\
0\end{array}$ & $\begin{array}{l}1 \\
2\end{array}$ & $\begin{array}{l}2 \\
2\end{array}$ & $\begin{array}{l}1 \\
1\end{array}$ & 7 & $\begin{array}{l}1 \\
8\end{array}$ & $\begin{array}{c}15 \\
5\end{array}$ & $\begin{array}{c}16 \\
3\end{array}$ & $\begin{array}{c}27 \\
8\end{array}$ \\
\hline Boards & $\begin{array}{l}3 \\
0 \\
\end{array}$ & $\begin{array}{l}1 \\
4\end{array}$ & 44 & $\begin{array}{l}2 \\
2 \\
\end{array}$ & $\begin{array}{l}1 \\
8 \\
\end{array}$ & 40 & $\begin{array}{l}2 \\
3 \\
\end{array}$ & $\begin{array}{l}1 \\
8\end{array}$ & $\begin{array}{l}4 \\
1 \\
\end{array}$ & $\begin{array}{l}2 \\
2 \\
\end{array}$ & $\begin{array}{l}1 \\
6 \\
\end{array}$ & 38 & $\begin{array}{l}3 \\
0\end{array}$ & $\begin{array}{l}1 \\
8\end{array}$ & 38 & $\begin{array}{l}1 \\
6\end{array}$ & 4 & $\begin{array}{l}2 \\
0\end{array}$ & $\begin{array}{l}1 \\
0\end{array}$ & 4 & $\begin{array}{l}1 \\
4\end{array}$ & $\begin{array}{c}16 \\
3\end{array}$ & 92 & $\begin{array}{c}24 \\
5\end{array}$ \\
\hline $\begin{array}{c}\text { Parasta } \\
\text { tals }\end{array}$ & $\begin{array}{l}2 \\
1 \\
\end{array}$ & $\begin{array}{l}1 \\
2 \\
\end{array}$ & 33 & $\begin{array}{l}1 \\
8\end{array}$ & $\begin{array}{l}2 \\
5 \\
\end{array}$ & 43 & $\begin{array}{l}2 \\
0 \\
\end{array}$ & $\begin{array}{l}2 \\
3 \\
\end{array}$ & $\begin{array}{l}4 \\
3 \\
\end{array}$ & $\begin{array}{l}2 \\
6 \\
\end{array}$ & $\begin{array}{l}1 \\
6 \\
\end{array}$ & 42 & $\begin{array}{l}2 \\
0 \\
\end{array}$ & $\begin{array}{l}1 \\
6 \\
\end{array}$ & 36 & $\begin{array}{l}1 \\
2 \\
\end{array}$ & 7 & $\begin{array}{l}1 \\
9 \\
\end{array}$ & 8 & 4 & $\begin{array}{l}1 \\
2 \\
\end{array}$ & $\begin{array}{c}12 \\
5 \\
\end{array}$ & $\begin{array}{c}10 \\
3 \\
\end{array}$ & $\begin{array}{c}22 \\
8 \\
\end{array}$ \\
\hline Total & $\begin{array}{l}9 \\
1\end{array}$ & $\begin{array}{l}7 \\
4\end{array}$ & $\begin{array}{c}16 \\
5\end{array}$ & $\begin{array}{l}9 \\
2\end{array}$ & $\begin{array}{l}9 \\
5\end{array}$ & $\begin{array}{c}18 \\
7\end{array}$ & $\begin{array}{l}8 \\
8\end{array}$ & $\begin{array}{l}9 \\
2\end{array}$ & $\begin{array}{l}8 \\
0\end{array}$ & $\begin{array}{l}9 \\
7\end{array}$ & $\begin{array}{l}8 \\
6\end{array}$ & $\begin{array}{c}18 \\
3\end{array}$ & $\begin{array}{l}7 \\
3\end{array}$ & $\begin{array}{l}7 \\
0\end{array}$ & $\begin{array}{c}13 \\
3\end{array}$ & $\begin{array}{l}4 \\
8\end{array}$ & $\begin{array}{l}3 \\
1\end{array}$ & $\begin{array}{l}7 \\
9\end{array}$ & $\begin{array}{l}4 \\
4\end{array}$ & $\begin{array}{l}1 \\
9\end{array}$ & $\begin{array}{l}6 \\
3\end{array}$ & $\begin{array}{c}53 \\
3\end{array}$ & $\begin{array}{c}46 \\
7\end{array}$ & $\begin{array}{l}10 \\
00\end{array}$ \\
\hline
\end{tabular}

Source: Planning, Research and Statistics Unit, Akwa Ibom State Secondary Education Board, (2006)

Key: $\quad M=$ Male

F - Female

T-Total

\subsection{INSTRUMENTATION}

The instrument for data collection was the Public Servants Questionnaire (PSOQ). Section A: dealt with demographic information, while Section B: dealt with the main variables of the study, eating disorder and depression. 
Eating Disorder and Depression Among Public Servants in Akwa Ibom State, Nigeria

\section{METHOD OF DATA ANALYSIS}

After collecting the data, raw scores were summed up, the mean and standard deviation were computed, and data further analyzed based on .05 alpha level, with a null hypothesis, using the Pearson Product Moment Correlation as follows:

\section{Hypothesis}

There is no significant relationship between eating disorder and depression among public servants in Akwa Ibom State

\section{STATISTICAL MEASURE}

To test this hypothesis the Pearson Product Moment Correlation was used. The result of the analysis is presented in table 2.

Table 2: Pearson Product Moment Correlation of Relationship between eating disorder and depression

\begin{tabular}{|c|c|c|c|c|c|}
\hline Variables & $\mathrm{N}$ & $\overline{\mathrm{X}}$ & $\mathrm{SD}$ & $\mathrm{r}$ & Sig. \\
\hline Eating disorder & 1000 & 9.923 & 1.339 & $.628^{*}$ & \\
\hline Depression & 1000 & 9.890 & 1.227 & & .000 \\
\hline
\end{tabular}

${ }^{*} \mathrm{P}<05, \mathrm{df}=998$, critical $\mathrm{r}=0.1946$

\section{RESULT AND DISCUSSION OF FINDINGS}

The result in table 2 produced a coefficient of .628* showing that, eating disorder significantly contributed to depression among public servants in Akwa Ibom State. The null hypothesis was rejected. The result farther indicates that, the correlation coefficient implied that the higher the eating disorder, the higher the degree of depression and vice versa.

Based on the findings, it was established that there was a significant relationship between eating disorder and depression in the group studied $\left(r=.628^{*}\right.$, critical $r=0.1946$ at $\left.\mathrm{df}=998, \mathrm{P}<.05\right)$. Kriz $(2002)$ reported that individuals with eating disorders experiences como-bid of diagnosis of mental illness.

Uher \& Treasure (2005) opined that, women with eating disorders show psychological distress, less helpful coping strategies, frequent sensation of hunger and less cognitive restraint. Kalat, 2004, also associated eating disorder with hormonal imbalance and abnormalities caused by damage in or around the hypothalamus, in the brain. Hence the public servants will only be mentally stable, if the job can take care of his or her socio-psychological needs.

\section{CONCLUSION AND RECOMMENDATIONS}

In conclusion therefore, depressed people should seek the services of social psychologists, marital counsellors, family doctors, mental health specialists, employee assistance programmes, social agencies, teaching hospitals, psychotherapists and clinical psychologists in the psychiatric hospital, who will be in a better medical outfit to properly assist them learn new eating behaviours that will lead to more satisfaction in life and "unlearn" counter-productive eating behaviour, that can cause or exacerbate depression.

It is however, recommended that, government should live up to their expectations, through provision of enabling working environment, to help eliminate work related depression. Finally, social psychologists and physicians need to be alert to the co-occurrence of depression and mental health, so as to organize enlightenment campaigns and creating healthy mental awareness to the public.

\section{SOURCES OF FUNDING}

This research received no specific grant from any funding agency in the public, commercial, or not-for-profit sectors. 
Dr. (Mrs.) Janet S Petters, and Dr. (Mrs.) Umo, Udeme Akaninyene

\section{CONFLICT OF INTEREST}

The author have declared that no competing interests exist.

\section{ACKNOWLEDGMENT}

None.

\section{REFERENCES}

[1] Baron, R., \& Bryne, D. (2002). Self-esteem: Attitudes about oneself. Social Psychology, 10; 171-175. New Delhi: Prentice-Hall of India Private.

[2] Cash, T. E. (1995). Developmental teasing about physical appearance: retrospective descriptions and relationships with body image. Social Behaviour and Personality, 23; 123-130.

[3] Catterin, J. Thompson, J. Thomas, C. \& Williams, R. (2000). Body image, mood and televised images of attractiveness: The role of social comparison. Journal of Social and Clinical Psychology, 19; 220-239.

[4] Crandall, C. S. (1995). Do parents discriminate against their heavy weight daughters? Personality and Social Psychology Bulletin, 21; 724-735.

[5] Cvetkovich, A. (2012). Depression: A public feeling. Durham, NC: Duke University Press. ISBN: 0822352389.

[6] Davey, C. G., Yucel, M. \& Allen, N. B. (2008). "The Emergence of Depression in Adolescence; Development of the Prefrontal Cartex and the Representation of Reward" Neuroscience \& Biobehavioural Reviews 32 (1): 119.

[7] Harrison, K. \& Cantor, J. (1997). The relationship between media consumption and eating disorders. Journal of Communication, $49 ; 40-46$.

[8] Haworth-Hoeppner, S. (2000). The Critical shapes of body image: The role of culture and family in the production of eating disorders. Journal of Marriage and the Family 3; 151-168. New York: Academic Press. http://www.ment.alhealth.eom/book/p.45-eat1.html.

[9] Kagan, J. Havernann, E. \& Segal, J. (1984). Psychology: An Introduction (5th Ed). San Diego. Harcourt Brace Jovanovich.

[10] Kalat, J. W. (2004). Biological Psychology 8, 90 - 366. Houston: New Leaf Publishing Services.

[11] Kriz, K.M. (2002). The Efficacy of Overeaters Anonymous in Fostering Abstinence in Binge-Eating disorder and Bulimia Nervosa. Virginia Polytechnics Institute and State University. Bulletin May, 2002.

[12] Lavine, H., Sweeney, D \& Wagner, S. (1999). Depicting Women as sex objects in television advertising; Effect on body dissatisfaction. Personality and Social Psychology Bulletin, 25; 1049- 1058.

[13] Long, P.W. (1993). Eating Disorders. Retrieved March 3rd, 2006. National Institute of Mental Health.

[14] Numbers, B. (1999) Time, 29. In Baron \& Bryne. Social Psychology, 10; 111- 173. Prentice-Hall of India, Private Limited, New Delhi.

[15] Rashid, T. \& Heider, I. (2008). "Life Events and Depression" (PDF). Annals of Punjab Medical College 2(1). Retrieved 15 October, 2012.

[16] Strong, S; Williamson, D; Netemeyer, R; \& Gear, J. (2000). Eating disorder symptoms and concerns about body differ as a function of gender and sexual orientation. Journal of social and psychology, 19; 240- 255.

[17] Uher, R. \& Treasure, J. (2005). Brain Lesion and eating disorders. Journal of Neurology, Neurosurgery and Psychiatry, 76; 825-857.

[18] Umo, U. A. (2003). Socio-Economic Determinants of Depression Among Public Servants in Cross River State, Nigeria. Masters' Degree Thesis. University of Calabar, Nigeria.

[19] Umo, U. A. (2009). Socio-Psychological factors and Depression among Public Servants in Akwa Ibom State, Nigeria. Ph.D Thesis/dissertation University of Calabar, Nigeria.

[20] Umo, U. A. (2017). The Various Dimensions of Depression and Solutions. University of Calabar Press, Nigeria. Unicalprintingpress2016@gmail.com.

[21] Vincent, M. A. \& McCabe, M. P. (2000). Gender differences among adolescents in family and peer influences on body dissatisfaction, weight loss and binge eating behaviours. Journal of Youth and Adolescence, 29; 205-221. 
Eating Disorder and Depression Among Public Servants in Akwa Ibom State, Nigeria

[22] Weiderman, M. (2000). Women's body image self-consciousness during physical intimacy with a partner. Journal of Sex Research, 37, 60-68.

[23] Weiner, S. (1998). The Addiction of overeating: Self-help groups as treatment models. Journal of Clinical Psychology, 54; 163 - 168.

[24] Yager, J. \& Anderson, A. E. (2005). Anorexia Nervosa. The New England Journal of Medicine, 353 (14); 14181488. Retrieved March 3, 2016 from Ovid web: http://mutex.gmv.edu.2076/gwl/ovidweb.egi. 